\title{
COMPUTER TOMOGRAPHY IN THE DIAGNOSIS OF ODONTOGENIC MAXILLARY SINUSITIS
}

\author{
Serova N.S., Evseeva E.V.
}

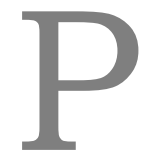

urpose. Determining the possibilities of modern radiology methods - multi-slice computed tomography (MSCT) and cone-beam computed tomography (CBCT) - in the diagnosis of inflammatory changes in the maxillary sinuses of odontogenic etiology.

Materials and methods. The study involved 180 patients $(100 \%)$ with maxillary sinusitis between the ages of 21 to 81 years, all patients underwent radiology examination.

Results. Low efficiency of radiography was revealed. From 180 patients (100\%) with maxillary sinusitis the usage of computed tomography helped to verify the diagnosis, to define the radiological characteristics of odontogenic etiology and to choose correctly the further treatment in 124 patients $(68,8 \%)$.

Conclusion. MSCT and CBCT are th e most informative methods in diagnostics of odontogenic maxillary sinusitis.

Keywords: multi-slice computed tomography, cone-beam computed tomography, maxillary sinus, odontogenic maxillary sinusitis.

Corresponding author: Evseeva E.V., e-mail: len4ikbaby@live.ru

For citation: Serova N.S., Evseeva E.V. Computer tomography in the diagnosis of odontogenic maxillary sinusitis. REJR 2019; 9(3):24-29. DOI:10.21569/2222-7415-2019-9-3-24-29.

Статья получена: $\quad 10.07 .19 \quad$ Статья принята: $\quad 22.08 .19$

\section{КОМПЬЮТЕРНАЯ ТОМОГРАФИЯ В АИАГНОСТИКЕ ОАОНТОГЕННЫХ ВЕРХНЕЧЕАЮСТНЫХ СИНУСИТОВ}

\author{
Серова Н.С., Евсеева Е.В.
}

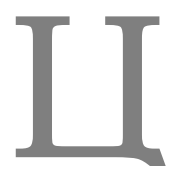

ель. Определение возможностей современных мучевых методов исследования - мультиспиральной компьютерной томографии (МСКТ) и конусно-лучевой компьютерной томографии (КАКТ) - в диагностике воспалительных изменений верхнечелюстных синусов одонтогенной этиологии.

Материалы и методы. Бымо обследовано 180 пациентов с верхнечелюстным синуситом (100\%) в возрасте от 21 до 81 года, всем пациентам бымо проведено рентгеномогическое исследование.

Результаты.

Выявлена низкая эффективность проекционных методов рентгенографии. Применение компьютерной томографии позволило из 180 обследованных пациентов $(100 \%)$ с верхнечелюстным синуситом у 124 больных $(68,8 \%)$ верифицировать диагноз, опредемить рентгенологические признаки одонтогенной этиологии выявленных изменений и грамотно подобрать дальнейшую тактику мечения.

\section{Выводы.}

MCKT и KАКТ - наиболее информативные методы в диагностике изменений верхнечелюстных синусов одонтогенной этиологии.

КАючевые слова: мультиспиральная компьютерная томография, конусно-лучевая компьютерная томография, верхнечелюстной синус, одонтогенный верхнечелюстной

I.M. Sechenov First Moscow State Medical University. Moscow, Russia.
ФГАОУ ВО Первый МГМУ им. И.М. Сеченова Минздрава России (Сеченовский университет).

г. Москва, Россия. 
синусит.

Контактный автор: Евсеева Е.В., len4ikbaby@live.ru

Для иитирования: Серова Н.С., Евсеева Е.В. Компьютерная томография

в диагностике одонтогенных верхнечелюстных синуситов. REJR 2019; 9(3):24-29.

DOI: $10.21569 / 2222-7415-2019-9-3-24-29$.

\section{Received: $\quad 10.07 .19 \quad$ Accepted: 22.08 .19}

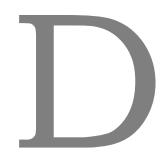

espite significant progress in dental care for the population, in recent years there has been an increase in the number of odontogenic maxillary sinusitis, which is associated with the rapid development of interventional dentistry [1, 2]. Maxillary sinusitis occupy one of the leading places among the inflammatory processes of odontogenic etiology [1 - 4]. Often, the connection of maxillary sinusitis with dental disease is underestimated by specialists, especially when it is not obvious, and odontogenic sinusitis is considered rhinogenic, which can lead to incorrect treatment tactics for patients. This primarily relates to chronic forms of odontogenic sinusitis with its relatively asymptomatic course [4 - 8].

According to Russian and foreign researchers, odontogenic maxillary sinusitis account for at least $5-8 \%$ of the total number of inflammatory diseases of the maxillofacial region $[9,10]$. This is due to the fact that the foci of chronic odontogenic infection are not always possible to establish during a visual examination of the oral cavity. They can also be concomitant with rhinogenic forms of sinusitis and aggravate their course. Often, chronic odontogenic maxillary sinusitis is detected by chance during an X-ray examination of the facial skull bones due to another pathology [5, 7].

A common cause of the odontogenic maxillary sinusitis development is errors in endodontic dentistry and dental implantation - carrying out instruments for root canal treatment (root needles, drills, canal fillers, pulp extractors), as well as filling material and an implant for the root apex of the tooth into the sinus cavity. Less often, foreign bodies in the sinus cavity are fragments of the teeth roots $[1,2,5,12]$. The reasons for the development of odontogenic maxillary sinusitis include sinus infection during surgery with perforation of the maxillary sinus cavity bottom: most often (up to $80 \%$ ) with accidental opening of the sinus during extraction and curettage of the hole after extraction of the first and second molars of the upper jaw, less often - during resection of the root apex, cystectomy, removal of retarded teeth, sequestrectomy, implant implantation, removal of tumors in this area $[1,10,15]$. odontogenic maxillary sinusitis remains with radiology methods. Traditionally, to assess the paranasal sinuses, X-ray is used in the nasal-chin projection, panoramic radiographs of the skull in the front and side projections.

To visualize the teeth, orthopantomography or intraoral contact radiography is used, which does not allow to reliably assess the condition of the maxillary sinuses $[11-14]$. With the introduction of modern high-tech methods of radiology diagnostics - multislice computed tomography (MSCT), cone-beam computed tomography (CBCT), magnetic resonance imaging (MRI) - many doctors began to abandon the classic X-ray methods because of their low informativeness [12 - 14]. Moreover, data on the state of the alveolar ridge, upper jaw teeth are not always included in the protocols for the description of the paranasal sinuses $[11,13]$. This can lead to untimely diagnosis and various local and general complications in such patients $[15,16]$.

\section{Purpose.}

Determining the possibilities of modern radiology methods - multi-slice computed tomography (MSCT) and cone-beam computed tomography $(\mathrm{CBCT})$ - in the diagnosis of inflammatory changes in the maxillary sinuses of odontogenic etiology.

Materials and methods.

In the period from 2013 to 2018 in the Radiology Department, Clinical Hospital No. 1 of the Sechenov University, 180 patients (100\%) with maxillary sinusitis of various etiologies were examined. In 124 patients (68.8\%), an odontogenic etiology of the disease was confirmed.

Analysis of the distribution of patients according to age and gender showed that from the examined patients with odontogenic maxillary sinusitis, the majority - 105 people $(58.3 \%)$ - were young and mature from 21 to 60 years old. There were 19 patients over 60 years old $(10.5 \%)$, the average age of the patients was 48 years (from 21 to 81 years). Dominated by women $(69 ; 38.3 \%)$ and 55 men $(30.5 \%)$ of working age.

A comparison of the clinical manifestations of odontogenic maxillary sinusitis and the radiological picture made it possible to conditionally divide patients into two groups: in 73 cases

As before, the leading role in the diagnosis of 


\section{RUSSIAN ELECTRONIC JOURNAL OF RADIOLOGY}

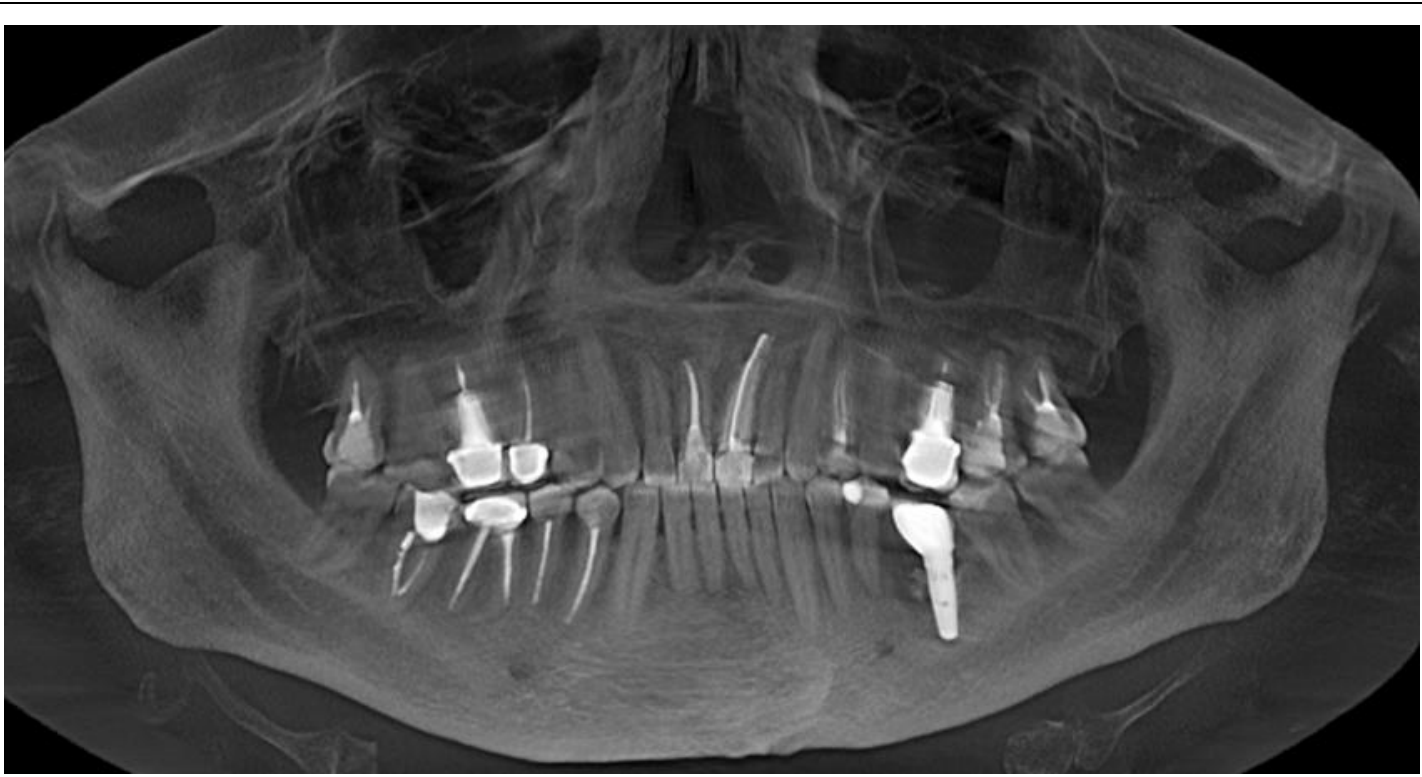

Fig. 1 a (Рис. 1 a)

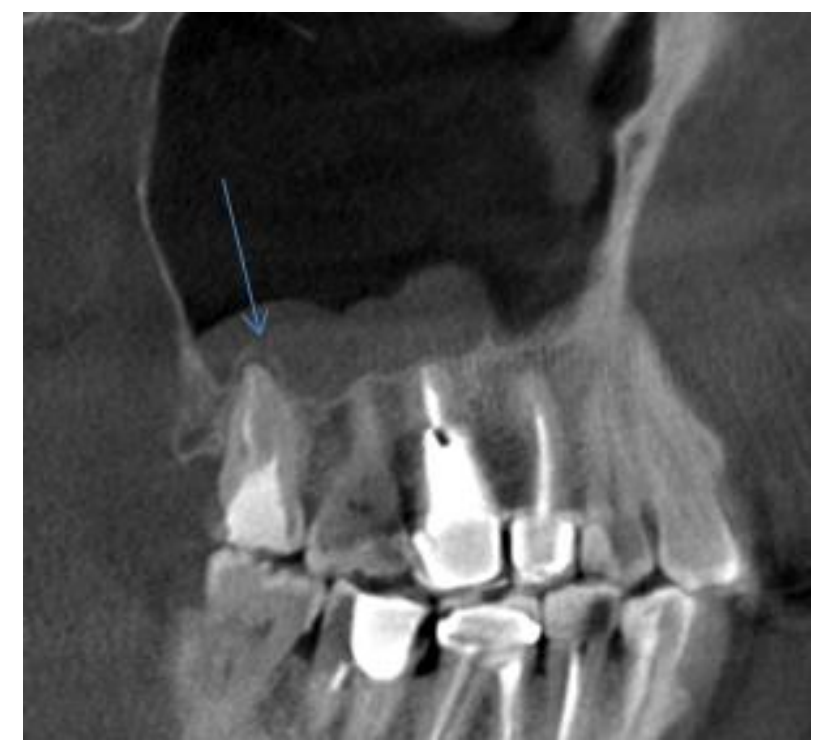

Fig. 1 b (Рис. 1 б)

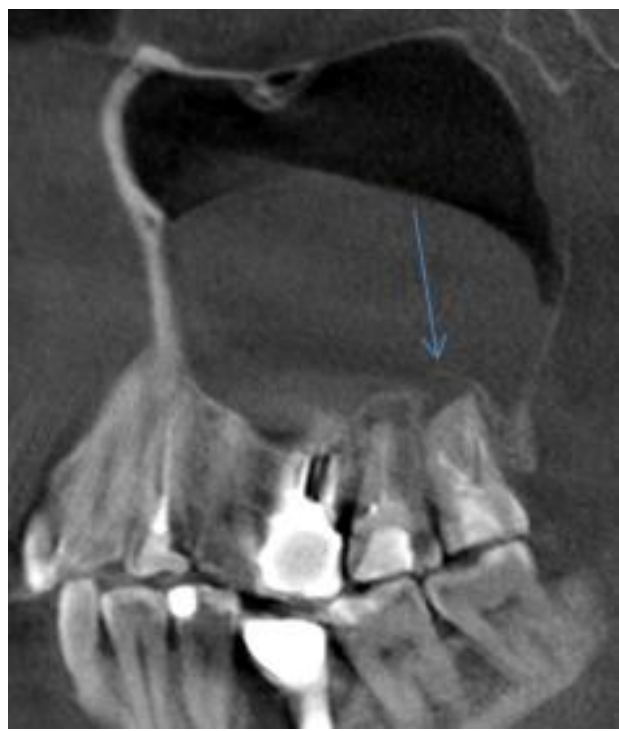

Fig. 1 с (Рис. 1 в)

Fig. 1. СВСT.

Panoramic (a) and multiplanar reconstructions of the right (b) and left (c) maxillary sinuses. Patient M., 37 years old. Diagnosis: bilateral odontogenic chronic maxillary sinusitis. There are CT signs of chronic granulomatous periodontitis of teeth 1.8, 2.7, 2.8 (in the form of foci of destruction at the apex of the roots, round in shape, with clear even contours). The lower walls of the sinuses are thinned, not visible in the periodontal area of teeth 1.8 and 2.8 (indicated by arrows). In the lower part of the right maxillary sinus, a parietal soft tissue formation, of a homogeneous structure, with a polycyclic upper contour, is determined. The left maxillary sinus is subtotally filled with soft tissue contents, of a homogeneous structure, with a rounded upper contour.

\section{Pис. 1. КАKT.}

Панорамная (а) и мультипланарные реконструкции правого (б) и мевого (в) верхнечелюстных синусов. Пациент М., 37 мет. Диагноз: двусторонний одонтогенный хронический верхнечелюстной синусит. Отмечаются КТ-признаки хронического гранулематозного периодонтита зубов 1.8, 2.7, 2.8 (в виде очагов деструкции у верхушек корней, округлой формы, с четкими ровными контурами). Нижние костные стенки синусов истончены, не прослеживаются в области периодонта зубов 1.8 и 2.8 (указаны стрелками). В нижнем отделе правого верхнечелюстного синуса определяется пристеночное мягкотканное образование, гомогенной структуры, с полицикличным верхним контуром. Аевый верхнечелюстной синус субтотально заполнен мягкотканным содержимым, гомогенной структуры, с округлым верхним контуром. 
(40.5\%), patients with acute inflammatory process in the maxillary sinus had corresponding clinical symptoms of the disease, and 51 patients $(28.3 \%)$ did not complain (chronic inflammatory process in the maxillary sinus).

A complete radiology study was carried out in all cases. All patients underwent computed tomography (MSCT or CBCT): MSCT for 83 patients (46.1\%), СВCT for 97 patients (53.8\%). 129 patients $(71.6 \%)$ underwent radiography of the paranasal sinuses in the nasal-chin, semi-axial projections. To clarify the condition of the teeth of the upper jaw, orthopantomography was performed (n $=180,100 \%)$ and intraoral contact radiography (n $=19,10.5 \%)$.

When analyzing diagnostic images, the criteria for odontogenic sinusitis were the following signs: the presence of a foreign body of metal density corresponding to a filling material or implant in the sinus cavity; deep caries and signs of periodontitis of premolars and molars of the upper jaw; destruction of the maxillary sinuses lower wall in the area of pathologically changed teeth.

\section{Results and its discussion.}

An analysis of the radiology diagnostic revealed signs of maxillary sinusitis in 124 of 180 cases $(68.8 \%)$ and to determine the odontogenic etiology of the disease. 73 patients (40.5\%) had characteristic clinical symptoms of the disease (headache, low-grade fever, sleep disturbance, a feeling of a "rush" of heaviness in the corresponding half of the face when the head was tilted anteriorly, nasal congestion on one side only); these patients were referred for radiology examination by otorhinolaryngologists. The remaining 51 people $(28.3 \%)$ did not show complaints from the maxillary sinuses; previously, they were referred for examination by dentists and maxillofacial surgeons according to the following indications: 25 patients $(13.9 \%)$ - to clarify the dental status, 15 patients $(8.3 \%)$ - before dental implantation, 11 patients $(6.1 \%)$ - for postoperative control after surgery on the upper jaw. In these cases, the revealed inflammation of the maxillary sinus was a diagnostic finding.

As believed, acute odontogenic inflammation

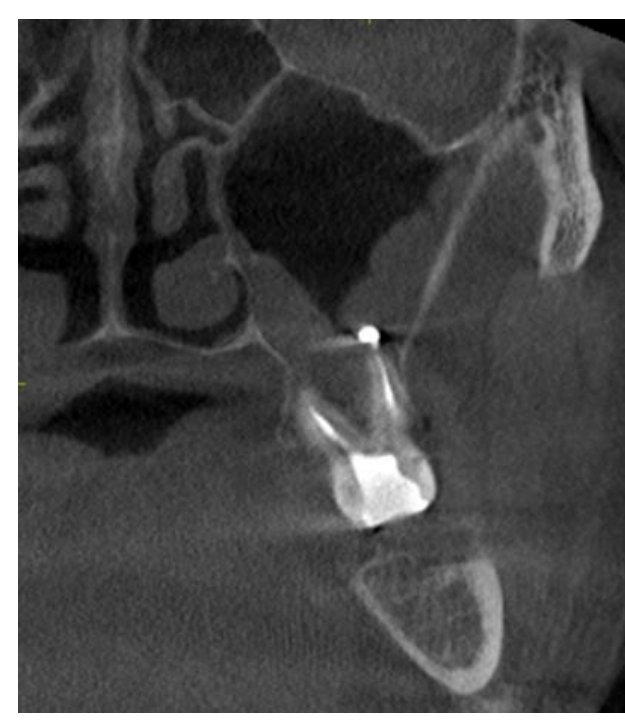

Fig. 2 a (Рис. 2 a)

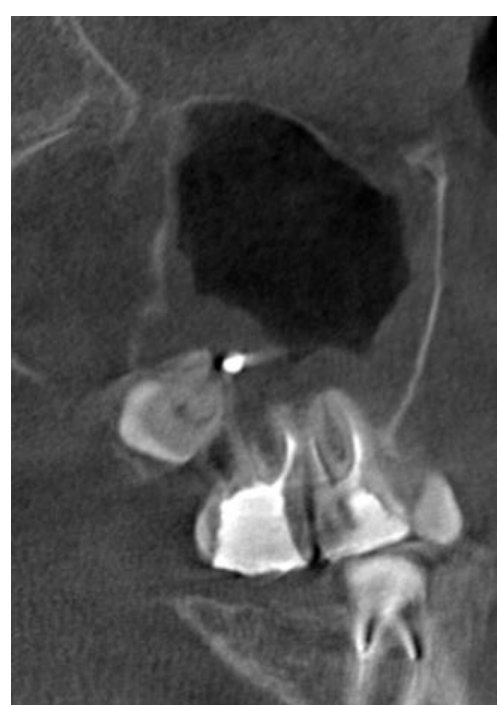

Fig. 2 b (Рис. 2 б)

\section{Fig. 2. MSCT.}

Coronary (a) and sagittal (b) reconstruction of the right maxillary sinus. Patient K., 29 years old. Diagnosis: rightsided odontogenic chronic maxillary sinusitis. The roots of teeth $1.6,1.7$ and 1.8 are immersed in the cavity of the maxillary sinus. Condition after endodontic dentistry 1.6 and 1.7 , with the removal of filling material at the apex of the palatine root 1.7. In the area of the 1.6-1.7 teeth roots, there is a rarefaction of bone tissue, with fuzzy uneven contours (radiological signs of granulating periodontitis). In the lower part of the sinus, a parietal soft tissue formation is determined, with a polycyclic contour, the bone walls of the sinus in this area are not traced.

Рис. 2. MCKт.

Корональная (а) и сагиттальная (б) реконструкции правого верхнечелюстного синуса. Пациент К., 29 мет. Диагноз: правосторонний одонтогенный хронический верхнечелюстной синусит. Корни зубов $1.6,1.7$ и 1.8 погружены в полость верхнечелюстного синуса. Состояние после эндодонтического мечения зубов 1.6 и 1.7 , с выведением пломбировочного материала за верхушку небного корня 1.7. В области корней зубов 1.6-1.7 отмечается разрежение костной ткани, с нечеткими неровными контурами (рентгенологические признаки гранулирующего периодонтита). В нижнем отделе синуса определяется пристеночное мягкотканное образование, с полицикличным контуром, костные стенки синуса в данной области не прослеживаются. 


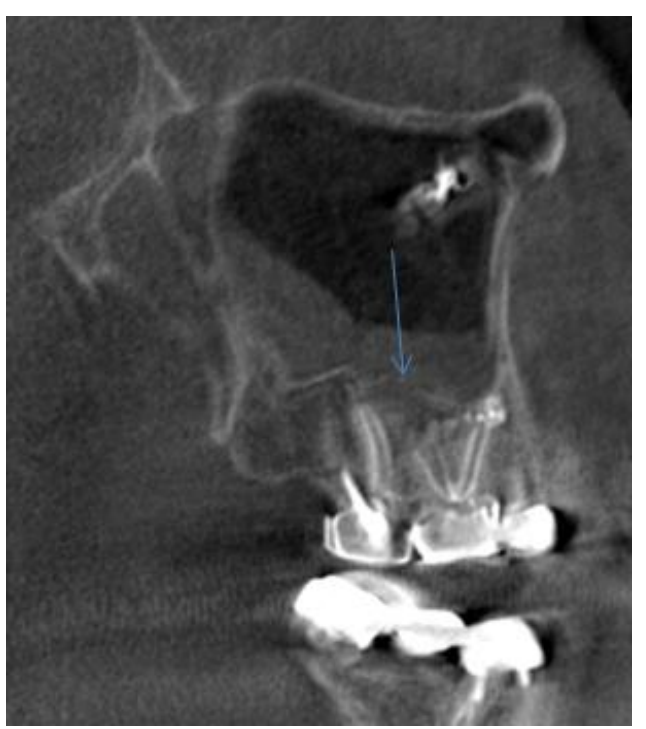

Fig. 3 (Рис. 3)

\section{Fig. 3. СВСT.}

Sagittal reconstruction, right maxillary sinus. Patient U., 48 years old. Diagnosis: right-sided odontogenic chronic maxillary sinusitis. Teeth 1.6 and 1.7 after endodontic treatment; removal of filling material beyond the tips of tooth roots 1.6 is noted (the material is located in the bone tissue of the alveolar bone and in the submucosal layer of the sinus). The rarefaction of bone tissue in the region of roots 1.6 and 1.7 is determined, the bone wall of the sinus in this area is not traced (arrow). In the lower part of the sinus, a thickening of the mucous membrane up to $10 \mathrm{~mm}$ is determined, in the upper medial part of the sinus a foreign body of irregular shape, metal density is visualized (corresponds to fragments of filling material).

\section{Pис. 3. KАKT.}

Сагиттальная реконструкция, правый верхнечемюстной синус. Пациент У., 48 мет. Диагноз: правосторонний одонтогенный хронический верхнече-

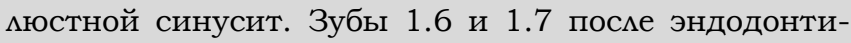
ческого мечения, отмечается выведение пломбировочного материала за верхушки корней зуба 1.6 (материал располагается в костной ткани альвеомярного отростка и в подслизистом слое синуса). Определяется разрежение костной ткани в области корней 1.6 и 1.7, костная стенка синуса в данной области не прослеживается (стрелка). В нижнем отделе синуса определяется утолщение слизистой обомочки до 10 мм, в верхнемедиальном отделе синуса визуализируется инородное тело, неправильной формы, метамлической плотности (соответствует фрагментам пломбировочного материала).

of the maxillary sinus develops within 1-3 days. Often, the cause is the inflammatory process of the upper jaw (acute or exacerbation of the chronic). Such conditions include complications of dental caries, periodontitis, periostitis, osteomyelitis, as well as suppuration of tooth cysts or granulomas $[7,8]$.

Typical complaints of patients with acute maxillary sinusitis were: difficulty in nasal breathing, rhinorrhea, loss of smell, headache and facial pain, a sensation of a "rush" of heaviness in the corresponding half of the face when the head is tilted anteriorly, low-grade fever, as well as nocturnal cough and sleep disturbance. Odontogenic sinusitis, in contrast to rhinogenic sinusitis, has the following distinctive features: isolated lesion of one of the sinuses, pain in the tooth or in periodontal tissues, preceding the disease, impaired face configuration due to swelling of the soft tissues of the cheek and pain during palpation of the anterolateral sinus wall.

In acute sinusitis, thickened mucous membranes, blackout, and fluid level were determined on radiographs. In chronic sinusitis, a decrease in the transparency of the sinus was noted.

When analyzing diagnostic images, the criteria for odontogenic sinusitis were the following signs: the presence of a foreign body of metal density corresponding to a filling material or implant in the sinus cavity; deep caries and signs of periodontitis of premolars and molars of the upper jaw; destruction of the lower bone wall of the maxillary sinuses in the area of pathologically changed teeth, as well as partial adentia of the upper jaw in the area corresponding to changes in the maxillary sinus.

During an X-ray examination in 51 patients $(28.3 \%)$ with acute maxillary sinusitis, thickened mucous membrane and/or subtotal darkening with a horizontal liquid level were determined on a panoramic radiograph. In 85 patients $(47.2 \%)$ there was a total decrease in sinus transparency, of which 45 patients (25\%) showed foreign bodies of metal density (corresponding to filling material) in the sinus cavity. However, the low contrast of fluid and soft tissues, the summation of the shadows made it difficult to objectively evaluate the obtained radiographs. To further assess the condition of the teeth of the upper jaw, all patients underwent orthopantomography, which did not allow a reliable assessment of the maxillary sinuses state, and 20 patients $(11.1 \%)$ accurately interpreted changes in the region of the teeth tops of the upper jaw (due to reflection of projection layers of complex anatomical structures).

According to the results of our study, $31 \mathrm{pa}-$ tients $(17.2 \%)$ showed signs of chronic periodontitis in the area of premolar and maxillary molars (fig. 1). Deep caries was diagnosed in 11 patients $(6.1 \%)$, cysts of the upper jaw in the area of the roots of premolars and molars were visualized in 13 cases $(7.2 \%)$.

Filling material was found in 45 patients (25\%) (fig. 2). Of these, 41 patients $(22.7 \%)$ in the submucosal layer of the lower sinus wall, and 4 


\section{RUSSIAN ELECTRONIC JOURNAL OF RADIOLOGY}

$(2.2 \%)$ in the upper section near the medial sinus wall (fig. 3). Failure of dental implantation was diagnosed in $15(8.3 \%)$ patients: the implant tip was immersed in the sinus cavity, which caused the development of chronic odontogenic maxillary sinusitis, as well as complications in the form of chronic polysinusitis ( $\mathrm{n}=11 ; 6.1 \%$ ).

In our study, 30 patients $(16.6 \%)$ had an absence of upper jaw teeth in the area corresponding to changes in the maxillary sinus, which also made it possible to judge the "odontogenicity" of maxillary sinusitis.

In all cases, computed tomography (MSCT or $\mathrm{CBCT}$ ) made it possible to accurately diagnose the form of the disease, determine the extent of the sinus lesion, assess the condition of the lower bone wall of the sinus (detect a violation of its integrity and message of the tooth socket with the sinus), determine the site of inflammation in the periodontium, and also detect foreign bodies in the maxillary sinus. Moreover, the MSCT and CBCT data were completely comparable and significantly superior to traditional X-ray diagnostic methods and had such advantages as the lack of

\section{References:}

1. Kruchinskij G.V. Damage to the bottom of the maxillary sinus and medical tactics. Stomatologija. 1994; 5:51-52. (in Russ.).

2. Sysoljatin P.G., Sysoljatin S.P. Damage to the maxillary sinuses, their treatment. Rossijskaja rinologija. 2000; 4:37. (in Russ.).

3. Piskunov I.S., Bobryshev S.V., Kaznacheev V.I., Shvachko N.A. Postoperative changes and hypogenesis of maxillary sinuses: differential diagnostic criteria in computed tomography. Russian Electronic Journal of Radiology. 2012; 4(2):127-130. (In Russ.).

4. Chibisova M.A., Dudarev A.L., Kuraskua A.A. Beam diagnostics in outpatient dentistry. SPb.: St.Petersburg Institute of Dentistry; 2002:38. (in Russ.).

5. Serova N.S., Slabkovskaya A.B., Ivanova D.V. Cone-beam computed tomography in diagnostics of dental anomalies. Diagnosticheskaja $i$ interventsionnaja radiologija. 2012;6(4):33-40. (in Russ.).

6. Piskunov C.Z., Bykanova T.G. Once again on sparing surgical treatment of odontogenic sinusitis. Rossijskaja rinologija. 2001; 1:34-36. (in Russ.).

7. Serova N.S., Evseeva E.V., Kleschevnikova K.Ju., Kovalinin V.V., Slepushkina A.V. Cone-beam computed tomography in the diagnostics of odontogenic maxillary sinusitis. Endodontiya Today. 2015; 2:68-71. (in Russ.).

8. Sysoljatin S.P. Odontogenous maxillary sinusitis: questions of superposition, high contrast resolution and the possibility of obtaining better reconstructions of images in different planes and 3D images of the zone of interest, as well as significant reduction in patient examination time and a reduction of radiation exposure. After computed tomography, treatment tactics were adjusted in 45 patients (25\%).

\section{Conclusions.}

1. High-tech methods of radiology diagnostics (MSCT or CBCT) are a necessary component of the comprehensive diagnosis of odontogenic maxillary sinusitis.

2. The use of computed tomography (MSCT or CBCT) allows determining the etiology of odontogenic maxillary sinusitis and to choose the right treatment tactics for patients.

3. MSCT or CBCT should be recommended to patients before and after endodontic dentistry and dental implantation, as well as during surgical interventions on the upper jaw in order to timely identify possible pathological changes in the maxillary sinuses (including asymptomatic).

etiology. Stomatolog. 2012; 6:32-9. (in Russ.).

9. Shargorodskiy A.G. Inflammatory diseases of maxillofacial area and neck. M.: SEI VUNMTS Ministry of Health; 2001:8897. (in Russ.).

10. Hirata, Y. A Clinical investigation of oro-maxillary sinusperforation clue to tooth extraction. Kokubyo Gakkai Zasshi. 2001; 68(3):53-56.

11. Buskina A.V., Gerber V.H. To the question about clinical classification of chronic odontogenic maxillary sinusitis. Vestnik otorhinolaryngologii. 2000; 2:20-22. (in Russ.).

12. Serova N.S. Dental volumetomography in solving some problems indentistry and maxillofacial surgery . Endodontiya Today. 2010; 2:55-57. (in Russ.).

13. Sysolyatin S.P., Sysolyatin P.G., Palkina M.O., Loginov O.V., Solop M.V., Baydik O.D. Issues of odontogenic maxillary sinusitisdiasnostics. The Siberian medical journal. 2010; 25(3):13-25. (in Russ.).

14. Ternovoy S.K., Arablinskiy A.V., Sinitsyn V.E. Curren radiology diagnostics of diseases of the paranasal sinuses. M.: I. M. Sechenov Moscow medical academy; 2004. (in Russ.).

15. Mehra P, Murad H. Maxillary sinus disease of odontogenic origin. Otolaryngol Clin North Am. 2004; 37(2):347-64.

16. Som P.M. Sinonasal cavities. in: P.M. Som, H.D. Curtin (Eds). Head and neck imaging. 4th ed. St. Louis, MO: Mosby; 2003. 